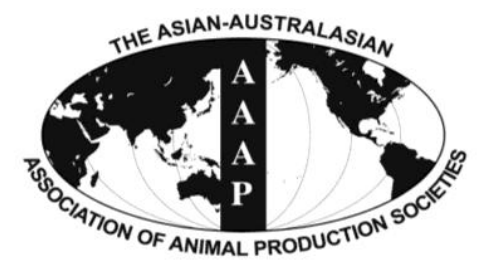

Asian-Aust. J. Anim. Sci.

Vol. 25, No. $6: 861$ - 868

June 2012

www.ajas.info

http://dx.doi.org/10.5713/ajas.2011.11294

\title{
Chemical Characterization and Water Holding Capacity of Fibre-rich Feedstuffs Used for Pigs in Vietnam
}

\author{
T. T. B. Ngoc, N. T. Len ${ }^{1}$ and J. E. Lindberg* \\ Department of Animal Nutrition and Forage, National Institute of Animal Sciences, Hanoi, Vietnam
}

\begin{abstract}
During two years, four samples per year were collected in Vietnam from rice bran, cassava residue, brewer's grain, tofu residue, soybean meal, coconut cake, sweet potato vines and water spinach for chemical analysis and assessment of water holding capacity (WHC). The selected feedstuffs represent fibre-rich plant sources and agro-industry co-products commonly used in pig feeding in Vietnam. The content ( $/ \mathrm{kg}$ DM) of crude protein (CP), ether extract (EE) and non-starch polysaccharides (NSP) varied between feedstuffs and ranged from 21 to 506 for CP, from 14 to 118 for EE and from 197 to 572 for NSP. Cassava residue had a high starch content of $563 \mathrm{~g} / \mathrm{kg} \mathrm{DM}$, while sweet potato vines, water spinach, coconut cake and soybean meal had a high content of sugars (63-71 $\mathrm{g} / \mathrm{kg} \mathrm{DM})$. The content of individual neutral sugars varied between feed ingredients, with the highest content of arabinose, galactose and glucose in tofu residue, the highest content of xylose in brewer's grain and the highest content of mannose in coconut cake. The content of uronic acid was high for cassava residue, tofu residue, sweet potato vines and water spinach $(57-88 \mathrm{~g} / \mathrm{kg} \mathrm{DM})$. The content of soluble non-cellulosic polysaccharides $(\mathrm{S}-\mathrm{NCP})$ was positively correlated $\left(\mathrm{r}^{2}=0.82\right)$ to the WHC. The content $(\mathrm{g} / \mathrm{kg} \mathrm{DM})$ of CP, NDF, neutral sugars, total NSP, total NCP, S-NCP and total dietary fibre in tofu residue, water spinach and coconut cake varied $(p<0.05)$ between years. In conclusion, diet formulation to pigs can be improved if the variation in chemical composition of the fibre fraction and in WHC between potential feed ingredients is taken into account. (Key Words: Vegetables, Agro-industry Co-products, Chemical Composition, Carbohydrates, Water Holding Capacity)
\end{abstract}

\section{INTRODUCTION}

The major fraction in diets for pigs is dietary carbohydrates, which can be divided according glycosidic linkages into sugars, oligosaccharides and two broad classes of polysaccharides, starch and non-starch polysaccharides. Non-starch polysaccharides (NSP) together with lignin, has been defined as the dietary fibre (DF) fraction in feedstuffs and food, and can be used as a collective measure of their fibre content (Trowell et al., 1976; Theander et al., 1994; Bach Knudsen, 1997).

Potential feed resources used for animals in Vietnam, as well as in many other countries in South-East Asia, derive primarily from the vegetable foods and agro-industry co-

\footnotetext{
* Corresponding Author: J. E. Lindberg. Department of Animal Nutrition and Management, Swedish University of Agricultural Sciences, P.O. Box 7024, 75007 Uppsala, Sweden. Tel: +46-(0) 18-672102, Fax : +46-(0)18-672995, E-mail: Jan.Erik.Lindberg @slu.se

${ }^{1}$ Department of Livestock Production, Ministry of Agriculture and Rural Development, Hanoi, Vietnam.

Submitted Aug. 22, 2011; Accepted Sept. 17, 2011; Revised Oct. 5, 2011
}

products, such as cassava leaves, sweet potato vines, water spinach, rice bran, cassava residue, brewer's grain and tofu residue. They represent under-utilized feedstuffs all having high fibre content, which may cause limitations in their use in diets for pigs, in particular for post-weaning and growing pigs, due to their bulky nature and a limited capacity to ferment fibre in pigs (Bach Knudsen and Jørgensen, 2001). Thus, in order to better utilize available fibre-rich feedstuffs in diets for pigs, their chemical and physical cheracteristics has to be described and taken into account in feed formulation.

Currently, the fibre fraction in feedstuffs used in pig feed is still commonly characterized by use of crude fibre and more frequently by use of the Van Soest detergent system (Van Soest et al., 1991) in which the fibre fraction is separated into neutral detergent fibre (NDF), acid detergent fibre (ADF) and lignin. However, despite considerable refinement in describing the fibre fraction compared with crude fibre, the detergent system has the limitation of not accounting for soluble carbohydrates. In order to more accurately describe the whole fibre fraction in feed and food, including both soluble and insoluble NSP, the Uppsala 
method (Theander et al., 1995) is today accepted as being the most relevant method to apply (Bach Knudsen, 1997).

The main objective of the study was to characterize the fibre fraction in selected fibre-rich feedstuffs, originating from green plants and agro-industry co-products and used in pig feed, with modern analytical methods, and to evaluate the variation in composition within feedstuff and between years.

\section{MATERIALS AND METHODS}

\section{Materials}

A total of 64 samples, comprising rice bran (RB), cassava residue $(\mathrm{CR})$, brewer's grain $(\mathrm{BG})$, tofu residue (TFR), soybean meal (SBM), coconut cake (CC), sweet potato vine (SPV) and water spinach (WSP) were analysed. Sweet potato vines and WSP are green plants that were collected from households in Hanoi (Vietnam) and the seasonal co-product CR (Cassava Starch Factory, Ha Tay, Vietnam) was collected 4 times during the first season in 2008 and the second season in 2009. The other samples were collected every third month during 2 years from agricultural processing factories producing all year, these were RB (Rice Processing Factory, An Giang, Vietnam), BG (HABECO, Ha Noi, Vietnam), TFR (from a tofu processing household in Hanoi, Vietnam), CC (Coconut Processing Factory, Ben Tre, Vietnam) and SBM (Cai Lan Vegetable Oil Company, Quang Ninh, Vietnam). Cassava residue, BG, TFR, SPV, and WSP were collected in fresh form and were freeze-dried, whereas RB, SBM and CC were in air-dry form. All samples were milled through a 0.5 $\mathrm{mm}$ screen and stored at room temperature until analysis.

\section{Analytical methods}

All analyses were performed in duplicate. Water holding capacity (WHC) was analysed using an adaptation of the filtration method proposed by Robertson and Eastwood (1981). A dry sample $0.5 \mathrm{~g}$ was soaked in $200 \mathrm{ml}$ of distilled water for $24 \mathrm{~h}$ at room temperature and then filtered through Whatman No. 1 filter paper. Samples filtered rapidly and filtration was completed after $10 \mathrm{~min}$. A sample of the residue was weighed (wet weight) before drying overnight in an oven at $105^{\circ} \mathrm{C}$ and reweighed (dry weight) which gave WHC.

Dry matter (DM) (967.03), crude protein (CP) (984.13), and ether extract (EE) (920.39) and ash (942.05) were analysed according to the standard AOAC methods (1990). The CP content was calculated as nitrogen $\times 6.25$. Neutral detergent fibre was determined by the method of Van Soest et al. (1991). Starch and sugars were analysed by an enzymatic method (Larsson and Bengtsson, 1983).

Total, soluble and insoluble NSP and their constituent sugars were determined as alditol acetates by gas-liquid chromatography (GLC) for neutral sugars, and by a calorimetric method for uronic acids using a modification of the Uppsala method (Theander et al., 1995) as described by Bach Knudsen (1997). Starch was removed from the sample in acetate buffer using termostatable $\alpha$-amylase and amyloglucosidase. Soluble polymers were precipitated with ethanol. Precipitated and insoluble polysaccharides were hydrolysed with $\mathrm{H}_{2} \mathrm{SO}_{4}$. Analyses of released neutral sugars were performed on an Agilent 6890 gas chromatograph equipped with flame-ionisation detector. A $30 \mathrm{~m} \times 0.32 \mathrm{~mm}$ i.d. narrow-bore capillary column (Supelco SP 2380, Cat No. 2-4116) was used. Klason lignin was measured gravimetrically as the insoluble residue to $12 \mathrm{M} \mathrm{H}_{2} \mathrm{SO}_{4}$. Total DF is defined as amylase-resistant polysaccharides plus Klason lignin.

$$
\begin{aligned}
& \text { Content of cellulose was calculated as: } \\
& \begin{aligned}
\text { Cellulose }= & \text { NSP glucose }\left(12 \mathrm{~mol} / \mathrm{L} \mathrm{H}_{2} \mathrm{SO}_{4}\right) \\
& \text {-NSP glucose }\left(2 \mathrm{~mol} / \mathrm{L} \mathrm{H}_{2} \mathrm{SO}_{4}\right)
\end{aligned}
\end{aligned}
$$

Total non-starch polysaccharide (T-NSP) content was calculated as:

$$
\begin{aligned}
\mathrm{T}-\mathrm{NSP}= & \text { rhamnose }+ \text { fucose }+ \text { arabinose }+ \text { xylose } \\
& + \text { mannose }+ \text { galactose }+ \text { glucose }+ \text { uronic acids }
\end{aligned}
$$

Total non-cellulosic polysaccharide (T-NCP) content was calculated as:

$\mathrm{T}-\mathrm{NCP}=\mathrm{T}-\mathrm{NSP}-$ cellulose

Soluble NCP (S-NCP) content was calculated as:

$\mathrm{S}-\mathrm{NCP}=\mathrm{T}-\mathrm{NCP}$-insoluble NCP $(\mathrm{I}-\mathrm{NCP})$

\section{Statistical analyses}

Data on chemical composition of individual feedstuffs was described by mean values and their standard deviation (SD) using descriptive statistics. The variation between years within the individual feedstuffs was analysed by oneway analysis of variance in Minitab software using the model;

$$
Y_{i j}=\mu+\alpha_{i}+\varepsilon_{j}
$$

Where $Y_{i j}$ is the observed dependent variable, $\mu$ the overall mean, $\alpha_{i}$ the effect of the year $(1,2), \varepsilon_{j}$ is the residual error. Mean values were considered different at a p-value $\leq 0.05$.

The correlation between WHC and S-NCP in the whole data set was analysed using linear regression analysis.

\section{RESULTS}

Soybean meal had the highest CP content $(506 \mathrm{~g} / \mathrm{kg}$ 
Table 1. Chemical composition of selected fibre-rich plant sources and agro-industry co-products $(\mathrm{n}=8)(\mathrm{g} / \mathrm{kg} \mathrm{DM})$

\begin{tabular}{|c|c|c|c|c|c|c|c|c|c|c|c|c|c|c|c|c|}
\hline & \multicolumn{2}{|c|}{$\begin{array}{l}\text { Cassava } \\
\text { residue }\end{array}$} & \multicolumn{2}{|c|}{$\begin{array}{c}\text { Tofu } \\
\text { residue }\end{array}$} & \multicolumn{2}{|c|}{$\begin{array}{c}\text { Brewer's } \\
\text { grain }\end{array}$} & \multicolumn{2}{|c|}{$\begin{array}{l}\text { Rice } \\
\text { bran }\end{array}$} & \multicolumn{2}{|c|}{$\begin{array}{c}\text { Sweet potato } \\
\text { vines }\end{array}$} & \multicolumn{2}{|c|}{$\begin{array}{c}\text { Water } \\
\text { spinach }\end{array}$} & \multicolumn{2}{|c|}{$\begin{array}{l}\text { Coconut } \\
\text { cake }\end{array}$} & \multicolumn{2}{|c|}{$\begin{array}{c}\text { Soybean } \\
\text { meal }\end{array}$} \\
\hline & Mean & $\mathrm{SD}$ & Mean & $\mathrm{SD}$ & Mean & $\mathrm{SD}$ & Mean & SD & Mean & $\overline{S D}$ & Mean & SD & Mean & SD & Mean & $\mathrm{SD}$ \\
\hline Crude protein & 21 & 4 & 211 & 25 & 308 & 42 & 116 & 30 & 159 & 23 & 264 & 31 & 207 & 34 & 506 & 19 \\
\hline Ether extract & 15 & 5 & 58 & 12 & 75 & 6 & 118 & 33 & 36 & 11 & 27 & 5 & 101 & 26 & 14 & 5 \\
\hline NDF & 405 & 30 & 461 & 60 & 576 & 30 & 440 & 64 & 435 & 36 & 384 & 33 & 619 & 42 & 200 & 29 \\
\hline Ash & 20 & 6 & 40 & 6 & 39 & 5 & 120 & 13 & 131 & 22 & 126 & 28 & 71 & 6 & 82 & 8 \\
\hline Total sugars & 2 & 1 & 1 & 1 & 8 & 4 & 20 & 7 & 63 & 29 & 71 & 23 & 70 & 9 & 64 & 15 \\
\hline Starch & 563 & 42 & 9 & 5 & 63 & 18 & 219 & 68 & 13 & 5 & 28 & 12 & 6 & 3 & 5 & 2 \\
\hline T-NSP & 306 & 20 & 572 & 81 & 366 & 22 & 254 & 35 & 307 & 27 & 290 & 19 & 398 & 24 & 197 & 11 \\
\hline Cellulose & 140 & 8 & 180 & 23 & 112 & 8 & 134 & 18 & 140 & 11 & 110 & 7 & 53 & 6 & 56 & 4 \\
\hline T-NCP & 166 & 7 & 392 & 59 & 254 & 15 & 120 & 18 & 167 & 8 & 180 & 12 & 345 & 20 & 141 & 9 \\
\hline I-NCP & 71 & 13 & 148 & 18 & 240 & 16 & 109 & 18 & 91 & 7 & 61 & 7 & 303 & 18 & 88 & 9 \\
\hline S-NCP & 95 & 11 & 244 & 52 & 14 & 6 & 11 & 4 & 76 & 10 & 119 & 17 & 42 & 6 & 53 & 7 \\
\hline
\end{tabular}

$\mathrm{NDF}=$ Neutral detergent fibre; T-NSP $=$ Total non-starch polysaccharides; T-NCP = Total non-cellulosic polysaccharides;

$\mathrm{I}-\mathrm{NCP}=$ Insoluble non-cellulosic polysaccharides; $\mathrm{S}-\mathrm{NCP}=$ Soluble non-cellulosic polysaccharides.

DM), followed by BG and WSP (264-308 g/kg DM). Tofu residue, $C C$, SPV and $R B$ had a $C P$ content in the range $116-211 \mathrm{~g} / \mathrm{kg} \mathrm{DM}$, and CR had the lowest CP content $(21$ $\mathrm{g} / \mathrm{kg} \mathrm{DM}$ ) (Table 1). It was only the TFR which showed a variable $\mathrm{CP}$ content between years $(\mathrm{p}<0.05)$ (Figure 1).

Brewer's grain, RB, CC and TFR were high in EE (58$118 \mathrm{~g} / \mathrm{kg} \mathrm{DM}$ ), whereas CR, SPV and WSP had a low content of EE (15-36 g/kg DM). In general, CR and the

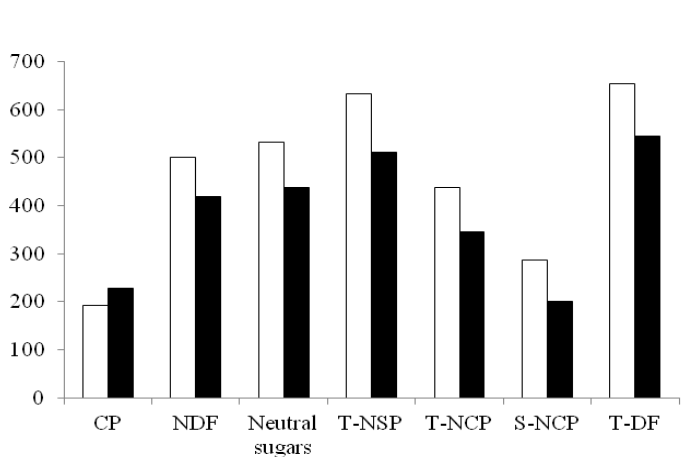

(A)

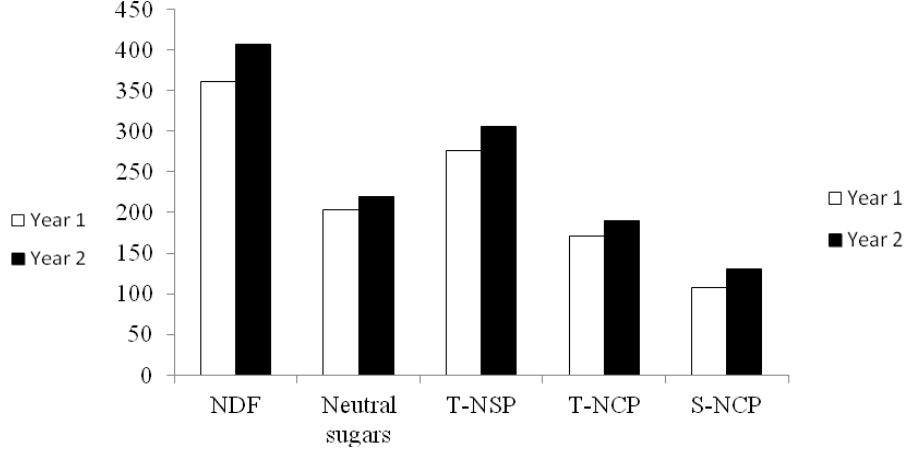

(B)

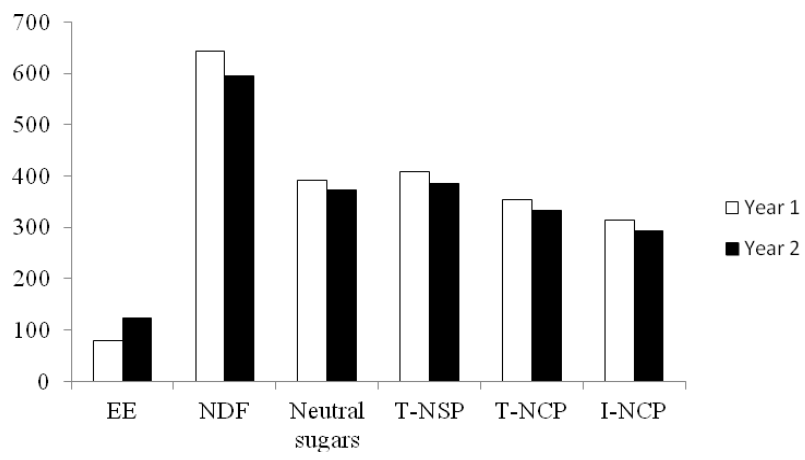

(C)

Figure 1. Average chemical composition ( $\mathrm{g} / \mathrm{kg} \mathrm{DM})$ of tofu residue (A), water spinach (B) and coconut cake (C) collected during two separate years. $\mathrm{CP}=$ Crude protein; $\mathrm{EE}=$ Ether extract; $\mathrm{NDF}=$ Neutral detergent fibre; T-NSP $=$ Total non-starch polysaccharides; $\mathrm{T}-\mathrm{NCP}=$ Total non-cellulosic polysaccharides; $\mathrm{I}-\mathrm{NCP}=$ Insoluble non-cellulosic polysaccharides; $\mathrm{S}-\mathrm{NCP}=\mathrm{Soluble}$ non-cellulosic polysaccharides. 
green plants (SPV and WSP) were lower in EE than the agro-industry co-products. It was only $\mathrm{CC}$ that showed a variation in EE between years $(\mathrm{p}<0.005)$ (Figure 1).

The NDF content was high in the green plants and in the agro-industry co-products (384-619 g/kg DM), with the highest NDF value recorded for CC (Table 1). All green plants and agro-industry co-products were higher in NDF than SBM. There was variation between years $(p<0.05)$ in the NDF content in TFR, WSP and CC $(\mathrm{p}<0.05)$ (Figure 1).

Ash content was low for CR, TFR and BG (20-40 g/kg $\mathrm{DM}$ ), while high values were recorded for RB, SPV, WSP, CC and SBM (71-131 g/kg DM) (Table 1).

The agro-industry co-products CR, TFR, BG and RB were all low in sugar content $(1-20 \mathrm{~g} / \mathrm{kg} \mathrm{DM})$, while the sugar content of the agro-industry co-product CC and the green plants was high $(63-71 \mathrm{~g} / \mathrm{kg} \mathrm{DM})$ and comparable to SBM (Table 1).

The content of starch varied a lot between the potential feed resources. Low to negligible starch content was recorded for TFR, SPV, CC, WSP and SBM (5-28 g/kg $\mathrm{DM}$ ), while intermediate starch content was found for BG and high starch content in CR (Table 1).

All vegetables and agro-industry co-products were higher in T-NSP content (254-572 $\mathrm{g} / \mathrm{kg} \mathrm{DM})$ than SBM (197 g/kg DM) (Table 1). Cellulose accounted for more than $50 \%$ of the T-NSP in RB, followed by approximately $45 \%$ cellulose in CR and SPV, and $31-38 \%$ cellulose in TFR, $\mathrm{BG}$ and WSP. The lowest value was found for $\mathrm{CC}$, where cellulose accounted for $13 \%$ of the T-NSP and the corresponding figure for SBM was $28 \%$ (Table 1).

The proportion of I-NCP was high in BG, RB and CC where it accounted for $88-94 \%$ of the T-NCP (Table 1). In SPV, the I-NCP proportion of T-NCP was $54 \%$, followed by values in the range $34-43 \%$ for CR, TR and WSP, and $62 \%$ for SBM.

The content of DF, followed the same pattern as the T-NSP content with high values for the vegetables and the agro-industry co-products (357-599 $\mathrm{g} / \mathrm{kg} \mathrm{DM}$ ) compared to SBM (222 g/kg DM) (Table 2). The proportion of I-DF was high in BG, RB and CC where it accounted for $91-97 \%$ of the T-DF (Table 2). In SPV, the I-DF proportion of T-DF was $84 \%$, followed by values in the range $59-74 \%$ for CR, TFR and WSP, and $76 \%$ for SBM.

The neutral sugars were the most abundant constituent of T-NSP accounting for $73 \%$ of the T-NSP in WSP and 81 $96 \%$ of the T-NSP in the other feed ingredients (Table 2). The content of individual neutral sugars varied substantially between feed ingredients. The content of arabinose, galactose and glucose were highest in TFR, the highest content of xylose was in BG and mannose was highest in CC. The content of uronic acid was high for CR, TFR, SPV and WSP (57-88 g/kg DM), while low values were found in $\mathrm{BG}, \mathrm{RB}$ and CC (11-14 g/kg DM) and intermediate in SBM (26 g/kg DM).

The content of Klason lignin was high $(103-160 \mathrm{~g} / \mathrm{kg}$ $\mathrm{DM}$ ) in BG, RB and SPV, followed by WSP, CC and CR (59-87 $\mathrm{g} / \mathrm{kg} \mathrm{DM})$ (Table 2). Tofu residue and SBM had the lowest content of Klason lignin (25-27 g/kg DM).

For TFR, WSP and CC there was variation between years $(p<0.05)$ in the content of neutral sugars, T-NSP, T-NCP, S-NCP, I-NCP, T-DF and S-DF (Figure 1).

The WHC varied greatly between feed ingredients with the highest values recorded for TFR and WSP, and the lowest value for RB (Figure 2). Soybean meal had an intermediate WHC. Overall, the WHC of the feed ingredients studied was closely correlated $\left(\mathrm{R}^{2}=0.82\right.$;

Table 2. Content of dietary fibre components in selected fibre-rich plant sources and agro-industry co-products $(\mathrm{n}=8)(\mathrm{g} / \mathrm{kg} \mathrm{DM})$

\begin{tabular}{|c|c|c|c|c|c|c|c|c|c|c|c|c|c|c|c|c|}
\hline & \multicolumn{2}{|c|}{$\begin{array}{l}\text { Cassava } \\
\text { residue }\end{array}$} & \multicolumn{2}{|c|}{$\begin{array}{c}\text { Tofu } \\
\text { residue }\end{array}$} & \multicolumn{2}{|c|}{$\begin{array}{c}\text { Brewer's } \\
\text { grain }\end{array}$} & \multicolumn{2}{|c|}{$\begin{array}{l}\text { Rice } \\
\text { bran }\end{array}$} & \multicolumn{2}{|c|}{$\begin{array}{l}\text { Sweet potato } \\
\text { vines }\end{array}$} & \multicolumn{2}{|c|}{$\begin{array}{c}\text { Water } \\
\text { spinach }\end{array}$} & \multicolumn{2}{|c|}{$\begin{array}{c}\text { Coconut } \\
\text { Cake }\end{array}$} & \multicolumn{2}{|c|}{$\begin{array}{c}\text { Soybean } \\
\text { meal }\end{array}$} \\
\hline & Mean & $\mathrm{SD}$ & Mean & SD & Mean & SD & Mean & SD & Mean & $\overline{S D}$ & Mean & SD & Mean & SD & Mean & SD \\
\hline Neutral sugars & 245 & 22 & 484 & 66 & 354 & 22 & 243 & 34 & 250 & 15 & 212 & 11 & 384 & 23 & 171 & 12 \\
\hline Rhamose & 4 & 0.4 & 8 & 1 & 1 & 0.1 & 1 & 0.1 & 5 & 0.5 & 4 & 0.3 & 1 & 0.1 & 3 & 0.3 \\
\hline Fucose & 2 & 0.3 & 10 & 2 & 0.4 & 0.1 & 0.4 & 0.1 & 1 & 0.1 & 1 & 0.1 & 1 & 0.2 & 4 & 1 \\
\hline Arabinose & 15 & 2 & 78 & 13 & 67 & 3 & 22 & 3 & 13 & 3 & 18 & 1 & 11 & 0.7 & 25 & 2 \\
\hline Xylose & 29 & 4 & 52 & 9 & 133 & 11 & 65 & 16 & 42 & 3 & 24 & 2 & 6 & 1 & 16 & 4 \\
\hline Mannose & 8 & 0.5 & 18 & 3 & 7.6 & 1 & 3.6 & 1 & 14 & 2 & 12 & 1 & 278 & 20 & 13 & 1.4 \\
\hline Galactose & 40 & 3 & 132 & 17 & 10 & 1 & 9 & 1 & 23 & 4 & 36 & 2 & 26 & 3 & 50 & 6 \\
\hline Glucose & 147 & 11 & 187 & 23 & 135 & 9 & 142 & 19 & 152 & 10 & 117 & 7 & 61 & 6 & 60 & 4 \\
\hline Uronic acid & 61 & 4 & 88 & 16 & 12 & 1 & 11 & 1 & 57 & 4 & 78 & 10 & 14 & 2 & 26 & 1 \\
\hline T-NSP & 306 & 20 & 572 & 81 & 366 & 22 & 254 & 35 & 307 & 27 & 290 & 19 & 398 & 24 & 197 & 11 \\
\hline Klason lignin & 59 & 9 & 27 & 7 & 112 & 9 & 103 & 25 & 160 & 41 & 87 & 21 & 68 & 10 & 25 & 5 \\
\hline $\mathrm{DF}$ & 365 & 32 & 599 & 77 & 478 & 29 & 357 & 57 & 467 & 36 & 377 & 34 & 466 & 28 & 222 & 12 \\
\hline I-DF & 270 & 24 & 355 & 31 & 463 & 30 & 346 & 57 & 391 & 37 & 258 & 19 & 424 & 26 & 169 & 13 \\
\hline S-DF & 95 & 11 & 244 & 52 & 14 & 6 & 11 & 4 & 76 & 10 & 119 & 17 & 42 & 6 & 53 & 7 \\
\hline
\end{tabular}

T-NSP = Total non-starch polysaccharides; DF = Dietary fibre; I-DF = Insoluble dietary fibre; S-DF = Soluble dietary fibre. 


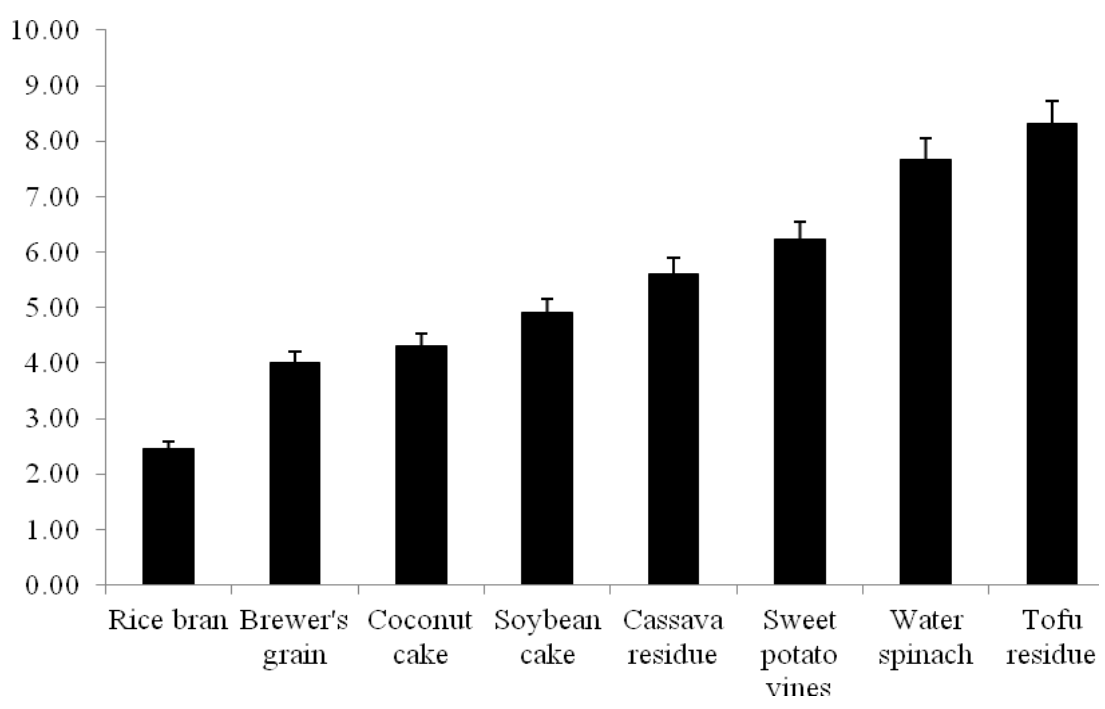

Figure 2. Water holding capacity $(\mathrm{kg} / \mathrm{kg}$ dry matter) in selected fibre-rich plant sources and agro-industry co-products $(\mathrm{n}=8)$. The standard error is shown by vertical bars.

$\mathrm{p}<0.001$ ) to the content of S-NCP (Figure 3). No other correlation was found between WHC and the components of the DF fraction.

\section{DISCUSSION}

Generally, the content of CP, EE and ash in green plants and agro-industry co-products were similar to those previously reported from Vietnam (NIAH, 2001) and other tropical countries (Gohl, 1981; Lekule et al., 1990). However, for some of the feed ingredients (e.g. tofu residue, coconut cake and water spinach) there was variation between years.

The plant cell wall can be divided into three layers: middle lamella, primary and secondary cell wall (Kunzek et al., 1999). The middle lamella connects single cells to form tissues. The main components of the middle lamella are pectin substances and it acts as a cementing substance in the middle lamella. In the primary cell walls, a cellulosexyloglucan framework (cellulose-hemicellulose network) is embedded in a pectin matrix and exists as microfibrils. When the cell growth has finished the cellulose microfibrils aggregate in the secondary wall and lignification can cause cell wall fixation. Thus, a change in chemical composition

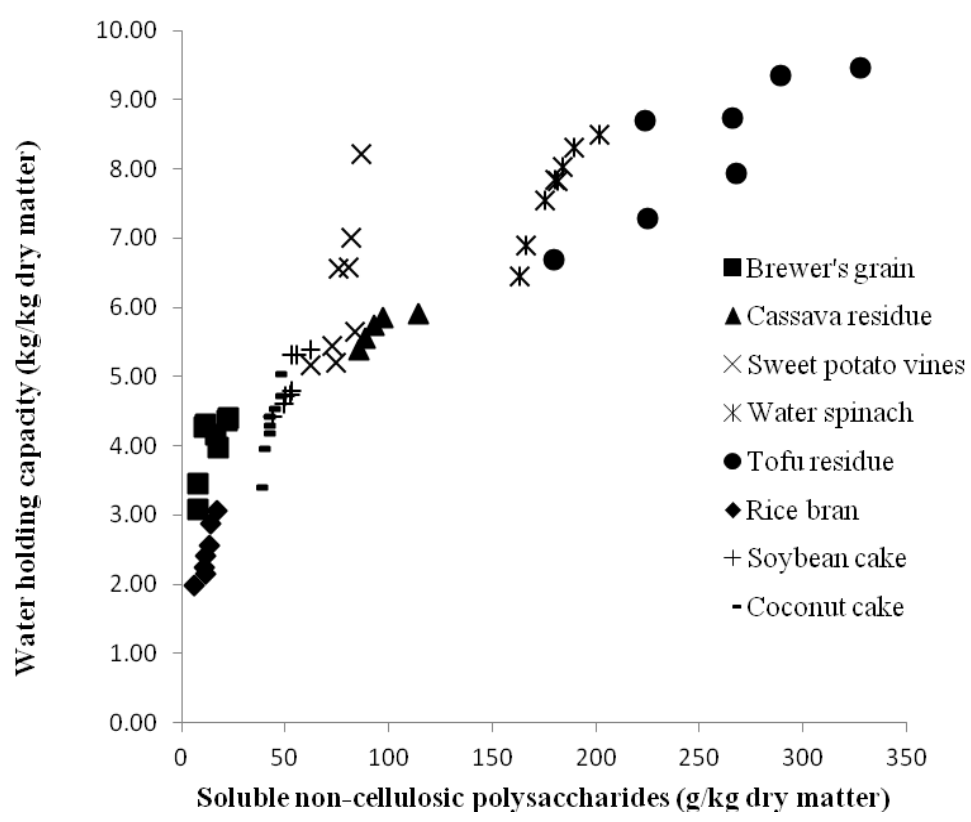

Figure 3. Correlation between water holding capacity (WHC, $\mathrm{kg} / \mathrm{kg} \mathrm{DM})$ and soluble non-starch polysaccharides (S-NCP, g/kg DM) in selected fibre-rich plant sources and agro-industry co-products $\left(\mathrm{WHC}=3.50+0.0214 \mathrm{~S}-\mathrm{NCP}, \mathrm{R}^{2}=0.82, \mathrm{p}<0.001\right)$. 
of the plant material and their co-products not only depends on the botanical origin of the plants and the type of processing applied, but also on the tissue type and the maturity at the plant at harvesting time. For example, while the nature of cellulose varies little between plants, the composition of the amorphous matrix usually shows considerable variation from tissue to tissue within plant and between plants. In cereals, which are monocotyledonous plants, the main cell wall NSP of whole grain cereals are arabinoxylans, cellulose and $\beta$-glucan with some variation between cereals (Bach Knudsen, 2001). In contrast, the amorphous matrix in dicotyledonous plants can differ markedly from that in monocotyledonous plants due to different tissue types, exemplified by the huge difference in content and properties of pectic substances (Bacic et al., 1988; McDougall et al., 1996).

Brewer's grain in the current study was higher in CP (308 vs. 215 g/kg DM) and lower in T-NSP (366 vs. 463 $\mathrm{g} / \mathrm{kg} \mathrm{DM})$ than reported by Serena and Bach Knudsen (2007). The chemical composition of BG will vary depending on barley variety, harvest time, malting and mashing conditions, and the quality and type of adjuncts added in the brewing process (Huige, 1994; Santos et al., 2003). Brewer's grain basically consists of the huskpericarp-seed coat layers that covered the original barley grain and depending on the evenness of the malting process more or less starchy endosperm and walls of empty aleurone cells may be included in the co-product. In consequence, the starch content will be negligible and the major components of BG will be the walls of the huskpericarp-seed coat, which are rich in cellulose and noncellulosic polysaccharides and lignin (Mussatto et al., 2006; Serena and Bach Knudsen, 2007), and protein, lipids and ash.

The chemical composition of $\mathrm{RB}$ is variable due to varieties used and in particular to the milling process (Bor et al., 1991). In Vietnam, the RB is classified into type 1, 2 and 3, based on $\mathrm{CP}$ and crude fibre (CF) content (NIAH, 2001) with CP descending and CF increasing going from type 1 to type 3 . The RB included in the current study was classified as type 2 . Rice bran, a by-product of rice polishing, constitutes about $10 \%$ of paddy rice and consists of the seed coat, the major part of the germ and the outer layer of the endosperm, and some small fragments of endosperm. Thus, due to the endosperm present RB can contain a fair amount of starch (100-550 g starch/kg DM) (Saunders, 1986; Bor et al., 1991). The RB analyzed in the current study had a starch content of $219 \mathrm{~g} / \mathrm{kg}$ DM. Free sugars in $\mathrm{RB}$ are concentrated in the aleurone layer and were low in the current study compared with values (3-5\%) reported earlier (Saunders, 1986). Most grains and their coproducts contain a large amount of arabinoxylans and cellulose (Bach Knudsen, 1997; Choct, 2006). The T-NSP and cellulose content in RB in the current study were in line with earlier data (Saunders, 1986).

The co-products (SBM and TFR) from soybean, a grain legume, differed markedly in chemical compositions due to different processing. Thus, while TFR is obtained from the extraction of soybean milk, SBM is the residue obtained from the extraction of soybean oil. To produce soybean milk, soybean seeds are soaked for a day and then ground with water before filtering. Consequently, TFR is lower in $\mathrm{CP}$ and sugars, and higher in ether extract and NSP fractions than SBM. Cellulose and xylans, which are the major NSP in cereal grains, are only found in the hulls or husks of most grain legumes (Choct, 1997). The major NSP in the cotyledon of legumes are pectic polysaccharides. The starch content in TFR and SBM was low and was lower than reported by others (Lekule et al., 1990; Bach Knudsen, 1997).

The T-NSP content in CC in the current study was lower than reported by Bach Knudsen (1997). However, composition of individual sugars in the NSP fraction was comparable, with predominance of mannans and with about $5 \%$ cellulose and trace amounts of other neutral sugars (rhamnose, fucose, arabinose and xylose). Coconut cake is the co-product obtained after milk extraction from the fresh coconut. After shelling and paring the residue is disintegrated and pressed in a screw press to separate the coconut milk from the solid materials. The coconut milk is used fresh or preserved and can be used for the preparation of virgin coconut oil, while the solid coconut residue is used in animal feeding.

Cassava residue, a co-product from the extraction of starch from cassava roots, was low in protein and high in fibre and starch. The fibre fraction was high in uronic acids and more than $50 \%$ of the T-NCP fraction was soluble. The predominant sugars in the NSP fraction were glucose, galactose and xylose. The high content of starch $(560 \mathrm{~g} / \mathrm{kg}$ DM) could due to entrapment in the cellulose-hemicellulose matrix (Divya Nair et al., 2011). Lower values $(500 \mathrm{~g} / \mathrm{kg}$ DM) were reported by Carta et al. (1999) and higher values $(620 \mathrm{~g} / \mathrm{kg} \mathrm{DM})$ by John et al. (2007). The variation in starch content in CR between studies is probably because most of the processing is done under poorly controlled technological conditions (Pandey et al., 2000).

Water spinach and SPV in the current study were high in $\mathrm{CP}$ and fibre (NDF and T-NSP). However, the CP values were lower and NDF values were higher than reported by Dung et al. (2002). This was probably due to differences between studies in time of harvest and in the sampling protocol (i.e. the cutting height of WSP and the length of SPV). The content of total sugars (63-71 g/ $\mathrm{kg} \mathrm{DM)} \mathrm{was}$ high in both WSP and SPV, while starch content was low (13-27 g/kg DM). These results were in line with earlier data (Woolfe, 1992). The T-NSP fraction was composed of 
$38 \%$ cellulose and $62 \%$ T-NCP in WSP, and $46 \%$ cellulose and 54\% T-NCP in SPV, respectively. Woolfe (1992) reported that the NSP fraction in SPV was composed of $34 \%$ cellulose and $66 \%$ T-NCP.

Hydration properties of the feed is very important for effective digestion to occur in the animal and can be characterized by the swelling capacity, solubility, WHC and water binding capacity (WBC). The terms WHC and WBC have been used differently in the literature since both reflect the ability of the fibre source to incorporate water within its matrix. According to Kunzek et al. (1999), the WBC describes the ability of a sample to bind water when exposed to an external stress, while WHC describes the ability to hold water within the feed matrix under atmospheric pressure. The WHC is usually obtained by centrifugation at high speed (McConnell et al., 1974; Robertson and Eastwood, 1981) and sometimes by filtration (Robertson and Eastwood, 1981). The WHC values reported in the current study were obtained by filtration. The filtration method is robust and easy to perform, and has been suggested to follow more closely the condition likely found in the gastro-intestinal tract and should resemble normal physiological conditions (Robertson and Eastwood, 1981). Results from the current study showed a strong correlation between content of S-NCP and WHC in plant material and agro-industry co-products. This could be due to the occurrence of more gaps within the cell matrix that can retain excess water in feed ingredients which are high in S-NCP. In agreement with our findings, Serena and Bach Knudsen (2007) have shown that the S-NCP fraction in coproducts from vegetable food and agro industries was linearly related to selected hydration properties, such as swelling and WBC.

\section{CONCLUSION}

There are marked differences in the chemical composition and water holding capacity between potential feed ingredients derived from green plants and agroindustry co-products. In particular, there were major differences in the composition and properties of carbohydrate fraction of the potential feed ingredients. It appears reasonable to assume that diet formulation to pigs can be improved if the variation in chemical composition, in particular of the fibre fraction, is taken into account.

\section{ACKNOWLEDGEMENTS}

This study was financed by Sida-SAREC (Swedish International Development Cooperation Agency Department for Research Cooperation), through the regional MEKARN program and the Swedish University of
Agricultural Sciences (SLU). The authors would like to thank the researchers at the Department of Animal Nutrition and Forage of the National Institute of Animal Science and Anna Greta Haglund who is the staff at the Department of Animal Nutrition and Management of SLU for their help in carrying out the study.

\section{REFERENCES}

AOAC. 1990. Official methods of analysis. 15th edition. Association of Official Analytical Chemists, Arlington, Virgina, USA.

Bach Knudsen, K. E. 1997. Carbohydrate and lignin contents of plant materials used in animal feeding. Anim. Feed Sci. Technol. 67:319-338.

Bach Knudsen, K. E. 2001. The nutritional significance of "dietary fibre" analysis. Anim. Feed Sci. Technol. 90:3-20.

Bach Knudsen, K. E. and H. Jørgensen. 2001. Intestinal degradation of dietary carbohydrates-from birth to maturity. In: Digestive Physiology in Pigs (Ed. J. E. Lindberg and B. Ogle). CABI Publishing, Wallingford. pp. 109-120.

Bacic, A., P. J. Harris and B. A. Stone. 1988. Structure and function of plant cell walls. Biochem. Plant 14:297-372.

Bor, S. L., S. Barber and C. Benedito de Barber. 1991. Rice bran: Chemistry and technology. In: Rice Utilization, Volume II, 2nd Ed. (Ed. Bor, S. L). Van Nostrand Reinhold, New York, USA. pp. 313-362.

Carta, F. S., C. R. Soccol, L. P. Ramos and J. D. Fontana. 1999. Production of fumaric acid by fermentation of enzymatic hydrolysates derived from cassava bagasse. Bioresource Technol. 68:23-28.

Choct, M. 1997. Feed non-starch polysaccharides: Chemical structures and nutritional significance. Feed Milling Intern. June Issue: 13-26.

Choct, M. 2006. Enzyme for the feed industry: Past, present and future. World's Poult. Sci. J. 62:5-15.

Divya Nair, M. P., G. Padmaja and S. N. Moorthy. 2011. Biodegradation of cassava starch factory residue using a combination of cellulases, xylanases and hemicellulases. Biomass Bioenergy 35:1211-1218.

Dung, N. N. X, L. H. Manh and P. Udén. 2002. Tropical fibre sources for pigs-digestibility, digesta retention and estimation of fibre digestibility in vitro. Anim. Feed Sci. Technol. 102:109-124.

Gohl, B. 1981. Tropical feeds. Feed information summaries and nutritive values. FAO, Rome.

Huige, N. J. 1994. Brewery by-products and effluents. In: Handbook of Brewing (Ed. W.A. Hardwick). Marcel Dekker, New York. pp. 501-550.

Kopinski, J. S., L. V. Kinh, D. Vinh, P. H. Ninh and B. Burren. 2007. Digestible energy, starch and cyanide content of sundried cassava residue in Vietnam. In: Manipulating Pig Production XI (Ed. J. E. Paterson and J. A. Barker), Australasian Pig Science Association, Werribee, Australia. pp. 118.

Kunzek, H., R. Kabbert and D. Gloyna. 1999. Aspects of material science in food processing: Changes in plant cell walls of fruits 
and vegetables. Z Lebensm Unters Forsch A 208:233-250.

Larsson, K. and S. Bengtsson. 1983. Bestämning av lätt tillgängliga kolhydrater i växtmaterial (Determination of nonstructural carbohydrates in plant material). Method description no 22 Uppsala, Sweden: National Laboratory of Agricultural Chemistry.

Lekule, F. P., H. Jørgensen, J. A. Fernández and A. Just. 1990. Nutritive value of some tropical feedstuffs for pigs: Chemical composition, digestibility and metabolizable energy content. Anim. Feed Sci. Technol. 28:91-101.

McConnell, A. A., M. A. Eastwood and W. D. Mitchell. 1974. Physical characteristics of vegetable foodstuffs that could influence bowel function. J. Sci. Food Agric. 25:1457-1464.

McDougall, G. J., I. M. Morrison, D. Stewart and J. R. Hillman. 1996. Plant cell walls as dietary fibre: Range, structure, processing and function. J. Sci. Food Agric. 70:133-150.

Minitab. 2000. Statistical software version 13.31. User's Guide to Statistics. Minitab, PA, USA.

Mussatto, S. I., G. Dragone and I. C. Roberto. 2006. Brewers' spent grains: Generation, characteristics and potential applications. J. Cereal Sci. 43:1-14.

NIAH. 2001. Composition and nutritive value of animal feed in Vietnam. National Institute of Animal Husbandry, Agricultural Publishing House, Hanoi, Vietnam.

Pandey, A., C. R. Soccol, P. Nigam, V. T. Soccol, P. S. L. Vandenberghe and R. Mohan. 2000. Biotechnological potential of agro-industrial residues: 2. Cassava bagasse. Bioresour. Technol. 74:81-87.
Robertson, J. A. and M. A. Eastwood. 1981. An investigation of the experimental conditions which could affect water-holding capacity of dietary fibre. J. Sci. Food Agric. 32:819-825.

Santos, M., J. J. Jiménez, B. Bartolomé, C. Gómez-Cordovés and M. J. del Nozal. 2003. Variability of brewers' spent grain within a brewery. Food Chem. 80:17-21.

Saunders, R. M. 1986. Rice bran: Composition and potential food uses. Food Rev. Int. 1(3):465-495.

Serena, A. and K. E. Bach Knudsen. 2007. Chemical and physicochemical characterisation of co-products from vegetable food and agro industries. Anim. Feed Sci. Technol. 139:109-124

Theander, O., P. Åman, E. Westerlund and H. Graham. 1994. Enzymatic/chemical analysis of dietary fibre. J. AOAC Int. 77:703-709.

Theander, O., P. Åman, E. Westerlund, R. Andersson and D. Pettersson. 1995. Total dietary fibre determined as neutral sugar residues, uronic acid residues, and Klason lignin (The Uppsala Method): Collaborative study. J. AOAC Int. 78:10301044.

Trowell, H. C., D. A. T. Southgate, T. M. S. Wolever, A. R. Leeds, M. A. Gassull and D. J. A. Jenkins. 1976. Dietary fibre redefined. Lancet 967.

Van Soest, P. J., J. B. Robertson and B. A. Lewis. 1991. Methods for dietary fibre, neutral detergent fibre and non-starch polysaccharides in relation to animal nutrition. J. Dairy Sci. 74:3583-3597.

Woolfe, J. A. 1992. Sweet potato: Untapped food resource. Cambridge University Press, Cambridge. 